\title{
Türkiye'de odun dışı orman ürünlerinin planlanmasında yöntem ve yaklaşım sorunu
}

\author{
Kenan Ok ${ }^{\mathrm{a}}(\mathrm{D})$, Mehtap Koç $\mathfrak{c}^{\mathrm{a}, *}$
}

\begin{abstract}
Özet: Türkiye ormancıllığında odun dıșı orman ürünlerine verilen önem özellikle 2000'li yıllarda artmıștır. Bu dönemde, Türkiye'de dört ayrı uluslararası odun dışı orman ürünleri toplantısı yapılmışıı. Ormancılık bilim dünyasının konuya yaklaşımını gösteren son üç toplantıda 282 bildiri sunulmuştur. Odun dişı orman ürünleri üretiminde yetki sahibi olan Orman Genel Müdürlüğü (OGM) ise, 2011 yılında Odun Dışı Ürün ve Hizmetler Dairesi Başkanlığı'nı kurmuş ve örgüt yapısını genişletmiş̧tir. $\mathrm{Bu}$ dönemde hazırlanan Ulusal Ormancılık Programı ile OGM Stratejik planlarında odun dışı orman ürünlerine daima yer verilmiş, bu ürünlerin sürekliliği önemsenmiştir. OGM, önceleri odun dış1 orman ürünlerinin üretim ve satışına odaklanmış düzenlemelerle çalışırken, 2013 ve 2016 yıllarında çıkardığı iki ayrı tebliğle bu ürünlerin "envanter ve planlanması" konusuna da yönelmiştir. Bu çalışmanın kapsam ve amacı; Türkiye'de yapılan uluslararası toplantılarda sunulan bildiriler ile OGM'nin geçerli yönetim anlayıșını temsil eden tebliğ kapsamında; odun dışı orman ürünlerinin tür ve ürün bazında sürekliliğini sağlayabilecek yönetim teknikleri, planlama modelleri ve süreklilik izleme göstergeleri önerme, içerme durumlarını saptamaktır. Yapılan incelemede, bilimsel çalışmaların odun dışı orman ürünlerinin sürekliliğini sağlayacak planlama yaklaşımlarının geliştirilmesine sınırlı destek verebildiği, uygulanan tebliğin içerdiği türe özgü bilgilerin çoklukla yıllık hasat alımını düzenleme ilkelerine odaklandığı saptanmıştır.

Anahtar kelimeler: Odun dışı orman ürünü, Planlama, Yönetim, Sürdürülebilirlik
\end{abstract}

\section{The problem of methodological approach to planning of non-wood forest products in Turkey}

\begin{abstract}
Non-wood forest products (NWFPs) has gained importance in Turkey since 2000s. During this period, four international NWFPs meetings took place in Turkey and reflecting different approaches of forestry scientists, in the last three meetings showing the approach 282 papers were presented. General Directorate of Forestry (GDF), the authority on NWFPs, established the Department of Non-Wood Forest Products and Services in 2011 and expanded the structure of the organization. NWFPs and sustainability have been continuously placed in National Forestry Program and Strategic Plans of GDF and the sustainability of these products have been considered. While GDF has focused on production and sales of NWFPs formerly, it has expanded the regulations to "inventory" and "planning" of these products by arranging two new communiques in 2013 and 2016. The scope and purpose of this paper is to investigate the degree of inclusion and proposal of management techniques, planning models and monitoring indicators suitable for the sustainability of the species and products under the limitations of papers presented at last three international meetings held in Turkey and communique numbered 302. As a result of this review, it was determined that scientific studies could give limited support to the development of planning approaches for NWFPs, while the communique containing species specific information has mainly focused on explaining the principles to arrange annual harvesting.
\end{abstract}

Keywords: Non-wood forest product, Planning, Management, Sustainability

\section{Giris}

Bütün dünyada olduğu gibi, Türkiye'de de odun diş1 orman ürünlerine (ODOÜ) ilgi artmaktadır. 2000 y1lında Menemen'de yapılan Uluslararası Odun Dışı Orman Ürünlerinin Hasatı semineri ile Türkiye'de bu alanda yeni bir dönemin başladığı düşünülebilir. Bu seminerle birlikte odun dışı orman ürünleriyle ilgili yaşanan gelişmelerin, yapılan kavramsal ve uygulamalı çalışmaların ilgililer ile paylaşıldığı, uluslararası katılımlı sempozyumlar serisi de başlamış̧ır. Menemen seminerinin ardından 2006 yılında Trabzon'da I. Uluslararası Odun Dışı Orman Ürünleri
Sempozyumu gerçekleştirilmiştir. ODOÜ yönetimiyle ilgili beklentileri karşılayamasa da, 2008 yilında Orman Amenajman Yönetmeliğinin değiştirilmesini de bu kapsamdaki önemli olaylar arasında kabul etmek gereklidir. 2011 y1lına gelindiğinde, OGM bünyesinde Odun Dışı Ürün ve Hizmetler Dairesi Başkanlığı kurulurken, Isparta'da II. Uluslararası Odun Dışı Orman Ürünleri Sempozyumu gerçekleştirilmiştir. Bu birimin kurulması, OGM'nin konuya verdiği önemin bir göstergesidir. OGM'nin odun dış1 ürünlerle ilgili çalışmaları, Odun Dışı Ürün ve Hizmetler Dairesi Başkanlığı öncesinde, 1995 yılında kabul edilen 283 sayıı Orman Tali Ürünlerinin Üretim ve Satış Esasları
\ a İstanbul Üniversitesi - Cerrahpaşa, Orman Fakültesi, Orman Mühendisliği Bölümü, Ormancılık Ekonomisi Anabilim Dalı, İstanbul, Türkiye

@ * Corresponding author (İletişim yazarı): mehtap.koc@istanbul.edu.tr

$\checkmark \quad$ Received (Geliş tarihi): 07.11.2018, Accepted (Kabul tarihi): 16.12.2018
Citation (Atıf): Ok, K., Koç, M., 2018 Türkiye'de odun dışı orman ürünlerinin planlanmasında yöntem ve yaklaşım sorunu. Turkish Journal of Forestry, 19(4): 391-402. DOI: $\underline{10.18182 / \mathrm{tjf} .480037}$ 
Tebliği'ne göre yürütülmüştür. Bu başkanlıkla birlikte, tebliğler de hızla yenilenmeye çalışılmış, 2013 yılında 297 sayılı Odun Dışı Orman Ürünlerinin Envanter ve Planlaması ile Üretim ve Satış Esasları Tebliği yayınlanmıştır. 2014 yılında bilimsel etkinliklerin bir yenisi gerçekleştirilmiş ve Kahramanmaraş'ta III. Uluslararası Odun Dışı Orman Ürünleri Sempozyumu yapılmıştır. OGM, 2016 yılında "302 sayılı Odun Dışı Orman Ürünlerinin Envanter ve Planlaması İle Üretim ve Satış Esasları" isimli tebliği (OGM, 2016) yayınlayarak, bu alandaki anlayışını güncellemiş ve resmen ortaya koymuştur.

Ülke bilim dünyası yapılan uluslararası toplantılar aracılığıyla ODOÜ konusunda bilgi üretme çabası gösterirken, uygulayıcı birim olan OGM bu alana özgü bir daire başkanlığ 1 kurarak ve çalışma biçimini netleştirme gayreti içerisinde tebliğler yayınlayarak, Türkiye'nin ODOÜ kapasitesini geliştirmeye çalışmıştır.

İçinde bulunulan dönemi; odun dişı orman ürünleri hakkında farkındalığın oluştuğu, konunun önemi hakkında bilincin sağlandığ , sorumlu kişi ve kurumların daha net tarif edildiği bir dönem olarak kabul etmek olanaklıdır. Ancak, her adımda ODOÜ'lerinin sürekliliğini sağlayabilecek bilimsel bilgileri üretebilen bir bilimsel yönelim içerisinde olunup olunmadığı, bu ürünlerden sorumlu uygulayıc1 birimlerin yeterli yönetsel yetkinliğe erişip erişmediğinin tartışılması gerektiği açıktır. Gerçekten de, bilim insanları bu konuda bildiriler yazmakta, tezler vermekte, araştırmalar yapmaktadır. Ülke ormancılık kurumları, ormanların yönetim planlarına ek olarak, odun dışı orman ürünü faydalanma planları yapmak gerektiğini bilmekte, hatta bu planların hazırlanma yöntemini 302 sayılı tebliğle (OGM, 2016) açıklamış durumdadır. Ancak, odun dışı orman ürünlerinin çeşitliliği anlaşılmış, bu çeşitlilikten sorumlu bir örgüt yapısı ortaya konmuş ve ekonomik önemi görülmüş olsa da, bu türlerin sürekliliğini sağlayabilecek planlama ve yönetim şeklinin halen tartışılır bir yapıdadır ve özellikle türe özgü bilgi ve yönetim süreçleri konusunda eksiklikler görülmektedir (Ok ve Tengiz, 2018). Doğada ürün oluşana kadar bekleyen, pazarın istediği ürünün varlığının oluşup oluşmadığının envanterini yapan ve ardından alıcısına satış işlemini gerçekleştiren bir yönetsel bakış ortaya çıkmıştır. Halbuki tıpkı odun hammaddesinde olduğu gibi, üretilmesi gereken ODOÜ'leri saptayan, bu ürünleri oluşturabilecek orman yapısını, vejetasyon biçimini tanımlayan ve bu yapıyı kurmaya yönelik ilk tesis, bakım ve hasat işlerini, süreklilik ilkesine göre yürüten, uygulamalarını izleyip değerlendirebilen bir bakışa geçilmesi gereklidir. Bu nedenle, artık çeşitlilik, ekonomik firsatlar veya sürekliliğin önemi konusunda farkındalık artırıcı araştırma ve yayınlardan çok, önemine inandığımız ODOÜ'lerin sürekliliğini tür veya ürün bazında garanti altına alabilen bir planlama ve yönetim düzenini kurmaya hizmet edecek araştırmalar yapmaya, bu araştırma sonuçlarını uygulamayı yönlendiren tebliğ içeriklerine dönüştürmek gereklidir.

$\mathrm{Bu}$ makalenin amac1, ODOÜ konusunda bilim dünyasında yapılan toplantılar ile uygulayıcı birimlerin temel anlayışını yansıtan güncel tebliğin, bu ürünlerin sürdürülebilirliğini garanti altına alabilecek bir metodik yaklaşımı ortaya koyup koyamadığını tartışmak ve özellikle sürdürülebilirlik ilkesine uyan bir faydalanmanın sağlanabilmesine yönelik planlama kapsamında öneriler geliştirmektir.

\section{Materyal ve yöntem}

Araştırma materyali iki grupta ifade edilebilir. İlk materyal grubunu, Türkiye'de 2000 sonrası yapılan odun dış1 orman ürünleri sempozyum, konferans ve kongrelerinde sunulan bildiriler oluşturmaktadır. Bu kapsamda yayınlanan üç bildiri kitabında yer alan özet ve tam metin yayınlar incelenmiş ve toplam 282 adet çalışma taranarak, içerik analizine tabi tutulmuştur. Poster bildiriler kapsam dış1 bırakılmıştır. İlk olarak anahtar kelimelerinde Yönetim ve Planlama kelimeleri yer alan bildiriler tespit edilmiştir. Bildiriler "Yönetim" anahtar kelimesi barındırma durumuna göre taranırken, ifadenin eş anlamlısı olarak "Amenajman" ve İngilizce karşılığı "Management” kelimeleri de kapsama dahil edilmiştir. İkinci aşamada, bütün bildirilerin özet bölümleri, planlama ve yönetim metodolojisi önerisi varyok şeklinde taranmıştır. Üçüncü ve son aşamada ise bütün bildiriler bir planlama değişkeni önerip, önermediğine göre sorgulanmıştır.

Araştırmanın ikinci grup materyali, 302 sayılı Odun Dışı Orman Ürünlerinin Envanter ve Planlaması İle Üretim ve Satış Esasları tebliğinden oluşmaktadır. Tebliğ içeriği, ODOÜ planlaması ve faydalanmanın sürekliliğiyle ilgili anlayış açısından sorgulanmış, hangi yöntemleri önerdiği, önerilen yöntemlerin uygulanabilir olup olmadığı, hazırlanan planlarla faydalanmanın sürekliliğinin izlenip denetlenmesine altlık olabilecek bir nitelikte olup olmadığ incelenmiştir.

\section{Bulgular}

\subsection{Sempozyum bildirilerinin içerik analizi bulguları}

Son üç Odun Dişı Orman Ürünleri Sempozyumunda sunulan toplam 282 adet bildirinin dağılımları ile yapılan tarama sonuçları, Çizelge 1'de verilmiştir.

Çizelge 1. Odun Dışı Orman Ürünleri Sempozyumlarında Bildiri Dağılımları ve İçerik Bulguları

\begin{tabular}{|c|c|c|c|c|c|c|c|c|c|c|}
\hline \multirow{3}{*}{ Toplantı Adı } & \multirow{2}{*}{\multicolumn{2}{|c|}{$\begin{array}{c}\text { Toplam } \\
\text { bildiri sayısı }\end{array}$}} & \multicolumn{4}{|c|}{ Anahtar kelimelerde } & \multicolumn{4}{|c|}{$\begin{array}{l}\text { Özet bölümü içinde en az bir türe } \\
\text { yönelik }\end{array}$} \\
\hline & & & \multicolumn{2}{|c|}{ Yönetim } & \multicolumn{2}{|c|}{ Planlama } & \multicolumn{2}{|c|}{$\begin{array}{c}\text { Planlama } \\
\text { metodolojisi }\end{array}$} & \multicolumn{2}{|c|}{$\begin{array}{c}\text { İzleme } \\
\text { değişkeni }\end{array}$} \\
\hline & Adet & $\%$ & Adet & $\%$ & Adet & $\%$ & Adet & $\%$ & Adet & $\%$ \\
\hline $\begin{array}{l}\text { I. Uluslararası ODOÜ Sempozyumu, 1-4 Kasım 2006, } \\
\text { Trabzon }\end{array}$ & 110 & 39 & 11 & 10 & 4 & 3,6 & 7 & 6,4 & 24 & 21,8 \\
\hline $\begin{array}{l}\text { II. Uluslararası ODOÜ Sempozyumu, 8-10 Eylül 2011, } \\
\text { Isparta }\end{array}$ & 48 & 17 & 1 & 2,1 & 1 & 2,1 & 5 & 10,4 & 17 & 35,4 \\
\hline $\begin{array}{l}\text { III. Uluslararası ODOÜ Sempozyumu, 8-10 Mayıs } 2014 \\
\text { Kahramanmaraş }\end{array}$ & 124 & 44 & 4 & 3,2 & 6 & 4,8 & 7 & 5,6 & 33 & 26,6 \\
\hline Toplam & 282 & 100 & 16 & 5,7 & 11 & 3,9 & 19 & 6,7 & 74 & 26,2 \\
\hline
\end{tabular}


Sempozyum kitaplarında yer alan bildirilerin özet bölümleri içerik analizine tabi tutulduğunda; en fazla (11 adet, \% 10) birinci sempozyum bildirilerinin anahtar kelimeleri arasında Yönetim ifadesi yer almaktadır. Birinci sempozyumda ilgilenilen yönetim alanlarına "Av ve Yaban Hayatı Yönetimi” (Şafak, 2006), "Sürdürülebilir Kaynak Yönetimi” (Açıkgöz, 2006), "Orman Amenajmanı” ve "Amenajman” (Baş ve Güler, 2006) şeklinde örnekler verilebilir. İkinci Uluslararası ODOU sempozyumunda sadece bir adet bildirinin (Başkent ve Küçüker, 2011) anahtar kelimeleri arasında "Yönetim" kavramı yer almıştır. Üçüncü Sempozyumda, sunulan toplam bildiri sayısı artmasına rağmen, sadece dört adet (\% 3,2) bildiride (NazariRad vd., 2014; Karahalil vd., 2014; Şafak ve Başar, 2014; Küçüker ve Başkent, 2014) yönetim kavramına yer verilmiştir.

Yukarıdaki tarama analizi; "planlama" ve "planning" terimleri için tekrarlandığında, tüm bildiriler içerisinde planlamanın, Yönetim kavramından daha az $(\% 3,9)$ yer aldığı tespit edilmiştir. İkinci ODOÜ sempozyumunda da sadece bir adet bildiride (Başkent ve Küçüker, 2011) planlama kavramı "Forest Management Planning" ifadesi ile anahtar kelimelerde yer bulmuştur. Bu bildiri aynı zamanda yönetim kelimesinin de kullanıldığı bildiridir. Planlama ifadesini direk anahtar kelime olarak kullanan bildiriler (Kiriş vd., 2006; Carus, 2014) olduğu gibi, "Çok Amaçlı Planlama” (Mısır vd., 2006), "Beş Yıllık Kalkınma Planları" (Türker, 2006a), "Ekosistem Tabanlı Çok Amaçlı Planlama" (Karahalil vd., 2014), "Peyzaj Planlama" (Altınçekiç vd., 2014), şeklinde kullanımlar da görülmektedir.

Anahtar kelime taramaları tamamlandıktan sonra, üç sempozyumda yayınlanan tüm bildirilerin özet bölümleri ayrıca içerik analizine tutulmuştur. Çizelge 1'de görüldüğü gibi her sempozyumda, ortalama 6 adet bildirinin özetinde, bir "Planlama ve Yönetim Metodolojisi önerisine" yer verilmiştir. Üç sempozyumda sunulan tüm bildiriler içerisinde planlama ve yönetim tekniği önerisi getirenlerin oranı ise \% 6.7 gibi düşük bir orandadır.

Birinci sempozyumda; Av ve yaban hayatı yönetimi için çözüm önerisinde bulunan (Şafak, 2006), 1hlamur türü özelinde envanter çalışması yapılmasını ve katılımcı yaklaşımla planlama gerekliliğini vurgulayan (Çiftçi ve Fırat, 2006), kestane ve fistıkçamı için mevcut amenajman planlarına entegre planlama ve yönetim gerekliliğini belirten (Kadığulları vd., 2006), su üretiminin mevcut amenajman planlarına yansıtılması stratejilerine değinen (Keleş vd., 2006) çalışmalar saptanmıştır.

İkinci sempozyumda yer alan bildirilerde; Kamerun için ODOÜ pazarlama bilgi yönetimi sistem modeli öneren (Samba ve Gertrude, 2011), OGM teşkilat organizasyon şemasında değişiklik ve ODOÜ Mühendisliği programlarının açılması gerekliliğini belirten (Demirci, 2011), Gümüşi Ihlamur için sürdürülebilir kullanım önerisi getiren (Korkusuz ve Dirik, 2011), bitkisel ve hayvansal kökenli ODOÜ'nin envanter metotlarını aktaran (Başkent ve Küçüker, 2011), Şimşirde süsleme amaçlı sürgün kesiminde silvikültürel müdahale usulleri öneren (Çoban ve Özalp, 2011) çalışmalar, yönetim ve planlamaya katkılarıyla dikkat çekmektedir.

Üçüncü sempozyum bildirilerinin taranması sonucunda; ODOÜ kapsamında bitki taksonu haritalandırması yaparak mevcut amenajman planlarına entegre edilmesi noktasında öneriler geliştiren (Karaköse ve Terzioğlu, 2014), zaman serisi analizi ile ODOU talep projeksiyonuna bağlı yönetim önerisi sunan (Türkoğlu vd., 2014), kekiğin orman amenajman planlarına entegre edilmesi çalışması yapan (Karahalil vd., 2014) çalışmalar, planlama metodolojisi önerisi kapsamında görülebilecek bildirilerdir.

Çizelge 1'den de görüldüğü gibi, birinci sempozyum bildirilerinin özet bölümleri en az bir "planlama ve yönetim izleme değişkeni bulundurma" durumuna göre analiz edildiğinde, bu kapsama girebilen 24 yayın tespit edilmiştir. $\mathrm{Bu}$ bildiriler arasında çeşitli türlere ait yıllık üretim miktarı (Alkan vd., 2006; Bilgin vd., 2006; Türker vd., 2006b) ile hasat zamanlarını (Var, 2006) çalışan bildiriler dikkat çekicidir. Defne türünün daha iyi yönetiminde standart oluşturmaya katkı yapabilecek üç çalışma tespit edilmiştir. Bu çalışmalarda; defnenin yaprak uçucu yağ ve meyve sabit yağının mevsimsel değişimi (Erden vd., 2006), yaprak verimi (Güler ve Baş, 2006), kurutma kayıp oranı (Yazıcı, 2006) konularında katkılar yapılmıştır. Her ne kadar, bir izleme değişkeni tanımlamak güç olsa da, mantar türleri için kullanım alanları (Lehtijärvi, 2006) ile yenebilme özellikleri ve yayılış alanları (Uzun, 2006) hakkında yapılmış çalışmalar vardır.

Sempozyum serilerinin ikincisinde; çeşitli türler için yıllık üretim miktarı (Ghanbari vd., 2011), dış ticaret değişkenleri (Kurt vd., 2011; Özçelik ve Koca, 2011) hakkında bildiriler görülmektedir. Fistıkçamının yaşa bağlı verim değişimi (Karademir vd., 2011) ile çeşitli türler için kimyasal değişken olarak uçucu yağ oranı (Parlak, 2011; Özderin vd., 2011; Özkan vd., 2011), antioksidan aktivite düzeyi (Şahin ve Üner, 2011; Özmen vd., 2011), biyopestisit özellikleri (Kitiş, 2011) hakkında yazılmış bildiriler, planlama ve yönetim alanında yapılması gerekenleri belirlemekte yön gösterici çalışmalardır.

Son sempozyumdaki bildiriler, bir planlama ve izleme değişkeni kapsamında içerik analizine tabi tutulduğunda, avcıların harcama eğilimini (Aydın ve Bekiroğlu, 2014), kent ormanı kullanıcılarının memnuniyet (Kulözü vd., 2014) ve farkındalık düzeylerini (Özer vd., 2014) çalışan sosyal içerikli yayınlara rastlanmaktadır. Çeşitli türlerde verim değişkeni için yapılmış çalışmalar (Küçüker ve Başkent, 2014; Sözbir vd., 2014; Karık vd., 2014) bu sempozyumda da yer almıştır. Kimyasal özelliklere dayalı uçucu yă̆ bileşimi (Karaman vd., 2014) değişkeni çalışan yayınlara son sempozyumda da rastlanmıştır.

\subsection{Sayılı tebliğdeki bulgular}

\subsubsection{Tebliğin genel hükümleriyle ilgili bulgular}

Odun Dışı Orman Ürünlerinin Envanter ve Planlaması ile Üretim ve Satış Esasları isimli 302 sayılı tebliğin amacı "başta sürdürülebilirlik ilkesi olmak üzere ormancilık ana ilkeleri doğrultusunda orman ekosistemlerinin odun hammaddesi dışında ürettiği odun dışı orman ürünlerinden yapılacak faydalanmaya ilişkin envanter, planlama, üretim, satış usul ve esaslarını belirlemektir" olarak ifade edilmiştir (OGM, 2016). Gerçekten de böylesi bir amaca hizmet edebilecek bir düzenlemeye ihtiyaç vardır. Ancak, tebliğin hedeflediği amaca erişebilecek bir içeriğe sahip olup olmadığı, uygulamaya yön verip veremediği noktalarında bilim dünyası ve uygulayıcı birimlerce sorgulanmalıdır. 
Odun dışı ürün yönetiminde envanter önemli bir aşamadır. 302 sayılı tebliğde Envanter "Plan ünitesi sinırları içerisindeki ODOÜ'lerin durumlarını tespit etmek amacıyla uygun metotlar kullanılarak yapılan ölçüm, sayım ve değerlendirmelerin tümü, alan envanteri ve verim envanteri şeklinde uygulanır" (OGM, 2016) şeklinde tanımlanmıştır. Bu tanıma ek olarak alan envanteri ve verim envanteri hakkında açıklamalara da yer verilmişse de, yönetilecek türe ve ürüne göre hangi metodun uygun metot olacağı, ölçülecek veya sayılacak değişkenin ne olduğu açıklanmamıştır. Hazırlanacak yönetim planının gerektirdiği izleme ve değerlendirme değişkenleri ile envanterde ölçülecek değişkenlerin uyumu sağlanmamıştır.

302 sayılı tebliğde faydalanma miktarı: “Bir ODOÜ'nün tüm yayılış alanında faydalanma yllına ait üretim zamanında toplanılacak miktarı", ifade eder şeklinde tanımlanmışken, bu miktarı kararlaştıracak kişinin hangi sınırlar içerisinde kalması gerektiği belirtilmemiştir. Tebliğin içerdiği faydalanma oranı tanımında da bu bilgiyi görmek mümkün değildir. Tebliğe göre faydalanma oranı; "Belirli bir yayılış alanında tespit edilerek envanter çalışmaları yapılan bir ODOÜ'nün popülasyonunun devamlılı̆̆ ve faydalanmanın sürdürülebilirliği açısından üretime konu edilecek miktarının verim miktarına olan yüzdesel oranını" (OGM, 2016) ifade etmektedir. Ancak bu durumda da "sürdürülebilir" verim miktarı ne olmalıdır sorusu ortaya çıkmaktadır. Tebliğe göre verim miktarı; “Hedef ODOÜ'nün örnek alan(lar) veya bu alan(lar) üzerinden hesaplanan tüm yayılış alanındaki sayısını ya da gram, kilogram, ton cinsinden ăgırliğını " (OGM, 2016) ifade etmektedir. Görüldüğü gibi, yukarıdaki tanım ve açıklamalardan yola çıkarak;

- Envanter yapılan varlığın ne kadarının toplanmasına izin verildiğinde süreklilik sağlanır? Hangi sınır aşılırsa süreklilik tehlikeye düşer?

- Bütün türlerde ve yetişme ortamlarında faydalanma oranı aynı midır?

- Türe ait bir artım düzeyi ölçmeden, artımla ilişkilendirmeden, faydalanma miktarının sürdürülebilir olup olmadığı nasıl anlaşılabilir?

şeklindeki soruların yanıtlarını, 302 sayılı tebliğde bulmak olanaksızdır.

Bitki veya hayvan, canlı bir varlıktan yapılacak yararlanmanın zamanı ve sıklığı, süreklilik için önemli kararlardır. 302 sayılı tebliğde de, bu kavramlara, haklı olarak yer verilmiştir. Ancak, tebliğ faydalanma periyodunu; "bir ODOÜ için aynı yayılış alanından ya da bir klsmindan yapılacak faydalanmanın yll olarak dönüş süresi " (OGM, 2016) olarak tanımlamaktadır. Tebliğ böylesi bir tanım yaparken bazı tür ve ürünlerde bir dönüş süresini belirtirken, tebliğde yer alan tüm türler, ürünler ve yetişme ortamları için uygulayıcıya ideal dönüş sürelerini söylememektedir. Faydalanma periyodunun ürüne göre mi, yoksa türün biyolojisine göre $\mathrm{mi}$ belirleneceğini de açıklamamaktadır.

Üretimin yapılacağı zaman konusunda da bir belirsizlik gözlenmektedir. Tebliğe göre üretim zaman1; "Bir ODOÜ için; türün biyolojisi, yetişme ortamı koşulları, faydalanılacak kisımları ve bunun gibi farklı etkenler doğrultusunda belirlenen toplamanın başlangıcı (dâhil) ile bitiş tarihi (dâhil) arasındaki süreyi" (OGM, 2016) ifade etmektedir. Ancak, tebliğde faydalanma periyodunda yapıldığı gibi, türden faydalanmanın yapılacağı yıl içi zaman, gün içi zaman, hava hallerine göre zaman, türe ve ürüne göre açıklanmadan, uygulayıcının bilgi ve deneyimine bırakılmıştır. Biyolojik varlığın ve ürünün sürekliliğinde önemli olan bu bilgilere tebliğde yer verilmezken, idari işlerin sürekliliği önemsenmiş ve "üretim zamanı henüz geçmemiş, farklı gerekçeler ve statülerince koruma altına alınmamış ODOÜ'lerden üretim talebi bulunanların faydalanma planlarl verim kaybina neden olunmadan yıllık iş programına bağlı kalınmaksızın öncelikli olarak yapılır" (OGM, 2016) şeklinde bir hükme yer verilerek, olası hasat fırsatları değerlendirilmek istenmiştir. $\mathrm{Bu}$ açıklama yapılırken, bir türün üretim zamanının geçip geçmediğinin neye göre anlaşılacağı, türün biyolojisinin, örneğin tohum dökme zamanının, üretim zamanını belirlemekte ne kadar ve nasıl etkili olacağı açıklanmamıştır.

Tebliğin "Envanter ve Planlama Heyetlerinin Oluşturulması" başlığı altında; "Envanter ve Planlama Heyetleri biri ilgili İşletme Şefi, diğerleri Bölge Müdürünün görevlendireceği biri başkan en az üç teknik elemandan oluşur. Heyetlerde görevlendirilecek yeterli sayıda personel bulunmamast veya mevcut personelin ilgili konularda uzman olmaması gibi durumlarda hizmet alımı yapılabilir" (OGM, 2016) denilmektedir. Bu iyi niyetli ifadelere rağmen, bir OGM çalışanının odun dışı orman ürünü planlama konusunda uzman olduğunun kanıtına veya göstergesine tebliğde yer verilmemekte, hizmet alımı yapılacak kişinin bu alanda uzman olduğunun nasıl anlaşılacağı, uygulayıcıya açıklanmamaktadır.

302 sayılı tebliğe göre "Verim envanteri, envantere konu ODOÜ'nün yaprak, sürgün, çiçek, meyve, kozalak, yumru, rizom, soğan gibi faydalanılan kısımlarının gerek nitelik gerekse nicelik bakımından toplanılmasının uygun olduğu üretim zamanlarında yapılır. Üretim zamani, ODOÜ'nün biyolojisine önemli oranda bağll olduğu kadar rakım, bakl, mikroklima gibi habitat özelliklerine de bağlıdır. Bu nedenle envanter çalışmalarının zamanlaması bölge ve yöreye göre değişkenlik gösterebileceğinden arazi çalışmaları bu husus göz önünde bulundurularak planlanır" (OGM, 2016). Bu bilgilere katılmamak, gerçekten mümkün değildir. Ancak, örneğin Defne yaprağı için, Akdeniz, Ege veya Marmara bölgesinde ve farklı rakımlarda en uygun üretim zamanının ne olduğu veya Ihlamur çiçeği veya Tavşan memesi (Ruscus spp.) rizomları için ideal envanter zamanının Türkiye'nin hangi bölgesinde hangi zamana denk geldiğini tebliğden öğrenmek mümkün değildir.

302 sayılı tebliğ zaman zaman bir ders kitabı içeriğinde detay bilgilere yer verse de, içeriklerinin yeterliliği sorgulanmaya muhtaçtır. Örneğin tebliğin "Hedef ODOÜ yayılış alanı içerisinde homojen bir dă̆ılım gösteriyorsa yayllış gösterdiği alanlarda sistematik; heterojen bir dağllım gösteriyorsa bilinçli tesadüfi örnekleme metodu tercih edilir. Bilinçli tesadüfi örnekleme metodunda sübjektif bir değerlendirme söz konusu olacă̆ından örnek alanlar yayılış alanını en iyi temsil edecek yerlerden özenle seçilmelidir. Envanter çalışmalarında alınacak örnek alan sayıs ve örnek alanların büyüklügü hedef ODOÜ'nün bölmecik içindeki yayılışına göre belirlenir" (OGM, 2016) şeklindeki ifadeleri "yeterlilik ve açıklık" açılarından incelemek yararlıdır. Uygulayıcının bir türün homojen veya heterojen yayıldığına karar verebilmesi için, bu konudaki ölçüyü bilmesi gereklidir. Bununla birlikte; homojenliğin ve heterojenliğin ölçüsü nedir? Bu ölçü türe göre değişir mi? 
Bir örneklem hem bilinçli hem tesadüfi nasıl olabilir? Bir mühendis ne yaparsa "örnek alan seçiminde" özenli davranmış olur? Şeklindeki soruların yanıtlarını tebliğde bulmak olanaksızdır. Üstelik tebliğde geçen "bilinçli tesadüfi örnekleme" istatistik kitaplarında tanımlanan örnekleme tekniklerine uymamaktadır. Bununla birlikte, kolayda örnekleme veya olasılıksız örnekleme yöntemleri denilen örnekleme yöntemleriyle, tebliğde geçen bilinçli tesadüfi örnekleme yöntemini aynı anlamda kabul etsek dahi, bu örnekleme yöntemlerinin ana kütleyi temsil etme yeteneği en düşük yöntemler olduğu (Nakip, 2006) bilinmelidir. Tebliğde yer alan örnek alanların şekil ve büyüklükleri ile homojen ve hetorojen yayılış halinde alınması gereken alanların ana kütleyi temsil kabiliyetleri çok şüphelidir ve bilimsel bulgulara, ilkelere dayandırılmadan idari bir karar ve anlayışla ortaya konduğu görülmektedir.

Diğer yandan, 302 numaralı Tebliğ'in 2.7.2 Faydalanmaya Konu Edilmeyecek Türler başlığı altında, "Bir yayılış alanındaki yayılışı braun blanquet skalasına göre nadir, serpili (münferit) ve örtme derecesi \% 5 'in altında olan türler ile ulusal mevzuatlartmı ya da taraf olduğumuz uluslararası anlaşmalarla mutlak koruma altına alınmış türler faydalanmaya konu edilmez" (OGM, 2016) denilmekte fakat envanteri braun blanquet anlayışıla yapmadan, bir türün bu skalaya göre durumunun belirlenemeyeceği, karşılaştırılamayacağı unutulmaktadır.

302 sayılı tebliğe göre "Ölçümler yaş ağırlık üzerinden yapılır. Bu ölçümlerde hedef ODOÜ'nün üretim tekniğine kesinlikle uyulmalı ve uygun toplama araçlart kullanılmalıdır. Hedef ODOÜ'nün birden fazla faydalanılan kısmı var ise her bir kısım ayrı ayrı üretilerek ayrı ayrı sayılır ve/veya ölçülür" (OGM, 2016). Tebliğde yer alan bu bilgileri, tebliğin ileri kısımlarında yer alan türe özgü açıklamalarla birlikte ele almak gereklidir. Böylesi bir karşılaştırma, birlikte değerlendirme yapıldığında, tebliğde hangi bir tür ve üründe üretim yapmak için en uygun tekniğin ne olduğunun sistematik bir biçimde ortaya konamadığı anlaşılmaktadır. Hangi araçların uygun toplama aracı olarak kabul edileceği belirsizdir. Örneğin Şimşir gibi, hem sürgünü hem odunu değerli olan türlerin yönetiminde nasıl hareket edileceği yeterince açıklanmamıştır.

302 Sayılı Tebliğde "Hedef ODOÜ'nün yayılış alanlarının kapsadiğı orman fonksiyonları, transport olanakları, sağladı̆̆ ekosistem hizmetleri ve biyolojik çeşitlilik gibi diğer bileşenlerle birlikte bütüncül ve katılımcı bir yaklaşımla değerlendirilerek sürdürülebilir faydalanmanın yöntem, usul ve esaslarl belirlenir" (OGM, 2016) denmekte fakat bunun nasıl başarılacağı açıklanmamaktadır. Tebliğde, "hangi ODOÜ’den ne miktarda faydalanılacă̆ına ya da ne kadarının doğaya bırakılacağına yapılan bilimsel araştırmalar ve uzman tavsiyeleri dikkate alınarak gözlemler sonucunda karar verilir. Türün biyolojisine göre yapılacak faydalanmalar dönüşümlü olarak planlanır. Örneğin defne sürgün faydalanmasının ardından 2-3 yıllık bir sürede kendisini yenileyebildiği için, üretimi 2-3 yılda bir yapılacak şekilde faydalanma bloklarina ayrilır" (OGM, 2016) denmektedir. $\mathrm{Bu}$ ifadeden anlaşılmaktadır ki, defnede aynı yaşlı bir yapı kurulmak istenmekte fakat tetar anlayışıyla mı yoksa ocaklar halinde oluşturulacak kök sürgünlerinden mi yararlanılacağı açıklanmamaktadır. Defneden söz edilmekte fakat örneğin Şimşir, Kocayemiş, Süpürge çalısı veya Ormangülü'nden söz edilmemektedir. $\mathrm{Bu}$ belirsizlikler altında, tebliğde ifade edilen "yapılacak faydalanma sınırl ve ekolojik süreçleri en az etkileyecek şekilde düzenlenmeli" ilkesinin nasıl hayat bulabileceği de belirsizleşmektedir. Oysa tebliğ hazırlayanların, uygulayıcıdan çok, bilimsel araştırmalar ve uzman tavsiyelerini dikkate alabilmeleri ve tebliğde yer vererek, bu bilgileri bir yönetim standardı veya kılavuzu halinde uygulayıcılara sunmaları beklenir.

302 sayılı Tebliğin Odun Dışı Ürünlerin Satış Usul ve Esasları bölümünün 4.1. Genel Usul ve Esaslar başlığı altında "Üretim işçiliği müşteriye ait olmak üzere açık artırmalı satış usulü odun dışı orman ürünlerin üretimi, aynı zamanda üretilen ürününün üreticiye satışını sağlayan bir satış usulüdür. Üretim işçiliği müşteriye ait olmak üzere açık artırmalı satış; İarenin üretim masrafi yapmadı̆̆

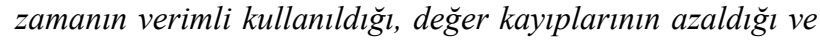
ürünün pazarlama garantisinin sağlandığı satış yöntemidir. Söz konusu satış usulü üretim ve satış garantisi sağladĭ̆ından mutlaka tercih edilmelidir" (OGM, 2016) denilmektedir. $\mathrm{Bu}$ ifade ile belirtilen aslında alivre satış tekniğidir. Odun hammaddesi satışlarında dikili satış olarak bilinen bu usulde, ormanın sahibi olmayan, pazarlamaya odaklanmış alıcının, oluşan ürünü alıp kalan meşcereye verebileceği olası zararlar sıklıkla sorgulanmaktadır (İlter ve Ok, 2012). ODOÜ'lerinde de hasada odaklanmış bir alıcının, kalan odun dışı ürün kaynaklarına zarar vermesi hiç olası değilmiş gibi, tebliğde "mutlaka tercih edilmesi" gerektiği belirtilmektedir.

302 sayılı tebliğin aynı başlığı altında; satışa konu ODOÜ'ler için "tartıya tabi yapraklı sürgünler dallarından ayrllip yabancı maddelerden temizlendikten sonra demetler halinde balyalanarak, tartıya tabi çiçek, meyve, yaprak, kök ve soğan gibi ürünleri ise toprak ve yabanc maddelerden temizlenmesine müteakip orman içi istif yerlerinde veya kantarlarda yaş olarak kabul edip tartarak satışa müstenit ölçü tutanăg d düzenlenecektir" (OGM, 2016) ifadesi yer almaktadır. Ancak, envanterde olduğu gibi, hangi ürünlerin tartıya tabi olduğu belirsiz bırakılmıştır. Bu durum envanteri yapılan ile hasat edileni ve pazarlananı tartışmasız bir "ölçüt" ile izlemeye engeldir. Tebliğde geçen demet, balyalamak veya balya terimleri tanımsız "birimlerdir" ve bir kişi, bölge veya zamanın balyası veya demeti ile diğerlerini karşılaştırmayı, hatta toplamayı engelleyen bir düzenlemedir. Her ne kadar, demet veya balya olsun, sonuçta tartılarak "yaş ağırlık" temeline dönülse de, ODOÜ piyasasında yerleşik birimlerle OGM'nin kullandığı birimlerin örtüşmesi gerekmektedir. Örneğin süsleme amaçlı kullanılan sürgünlerde toplayıcılar balya veya demet birimini kullanırken, OGM ağırlık birimini kullanmakta, çiçek borsaları ve diğer aracılar ile çiçekçiler de balya veya demeti tercih etmektedir. Ok ve arkadaşlarının saptadığı gibi, ODOÜ yönetiminde sağlıklı bir takip, izleme ve değerlendirme yapabilmek için kullanılan birimler konusundaki belirsizliklerin giderilmesi gereklidir (Ok vd., 2012).

302 sayılı tebliğ içerisinde pek çok tekrar ve takdim tehir hataları bulunmakla birlikte, Tebliğin, 4.6.Odun Dışı Ürünlerin Orman Kanunu 37 inci Maddesi Kapsamında Satışı başlığı altında, esasen çok doğru fakat uygulayıcıya yol gösterme yeteneği tartışılabilir başkaca ifadelere yer verilmiştir. Bu başlıkta yer alan işletme şefliği; "söküm ve toplama yapılacak sahaların bölme numaralarını, mevkiini, hudutlarını, satışa istinaden üretilecek ürünün ne olduğunu, ürünün özelliklerini, üretim zamanını ve tahmini miktarını içerecek şekilde Orman Kanunu 40. maddesi hükümleri 
çerçevesinde üretim şartnamesi ile birlikte ilan eder" (OGM, 2016) denmektedir. Aynı başlık altında, "Devlet ormanlarında mevcut ă̆aç, ağaççı ve floradan elde olunacak odun dişı orman ürünleri üretimi ikinci bölümde ayrıntılı olarak anlatılan Faydalanma Planları çerçevesinde yapılacaktır. Yapllan plan hükümleri ve ürün veren türün ve ürünün özellikleri göz önünde bulundurularak şartnameler hazırlanacaktır" (OGM, 2016) hükmü yer almaktadır. Tebliğe göre "Faydalanma planına bağlanmamış hiç bir ürünün üretimine izin verilmeyecektir. Planlarda ve şartnamelerde belirtilen üretimlerle ilgili talimatlara uygun üretim takvimi, tekniği ve verim yüzdeleri uygulanacaktır. Büyümenin devam ettiği zamanlarda, olgunlaşmamış ve tohumlarını olgunlaştıramamış ürünlerin toplanmasına, üretim tekniği uygun olmayan metotlarla üretim yapılmasına, uygun olmayan depolama işlemlerine katiyen müsaade edilmeyecektir" (OGM, 2016). Tebliğde yer alan fakat nasıl uygulanacağı açıklanmayan bu ifadelerin anlam kazanabilmesi için, 302 sayılı tebliğe ek talimatların çıkarılması gerektiği açıktır. Ancak bugüne kadar yayınlanan hangi ilgili talimatta ve hangi ürün için uygun üretim takvimi tanımlandığı, türe ve ürüne özgü en uygun üretim tekniğinin hangi düzenlemede gösterildiği, yetişme ortamı koşullarına göre verim yüzdesi değişimlerinin nasıl uygulamaya aktarılacağının ne zaman ortaya konduğu bilinmemektedir. ODOÜ yönetiminden sorumlu yerel yöneticilerin, hangi türde hangi üretim tekniğinin uygun olacağı konusunda karar verebilmesine yardımcı hangi yayınların veya talimatların bulunduğu merak konusudur. $\mathrm{Bu}$ durum depolama standartları veya uygunluğu için de geçerlidir. Bu nedenle, 302 sayılı tebliği destekleyecek talimatların biran önce hazırlanması gereklidir.

302 sayılı tebliğe göre "Odun Dışı Ürünlerinin Orman Kanunu Ek-12nci Maddesi Kapsamında Satışı" yapılabilmektedir. Bu kapsamda yapılan satışlarda sahalar; "öncelik sırasina göre köy tüzel kişiliklerine, tarımsal kalkınma kooperatiflerine, 5200 sayıl Kanunla kurulmuş üretici birlikleri ve birliklere velveya yöre halkına faydalanmayı talep ettikleri sahaların bakımlarını yapmaları koşulu ile tarife bedeli karşılı̆̆ında" (OGM, 2016) verilebilmektedir. Bu işlem açıklanırken "Yönetim planı yapılan sahalarda tespit edilen odun dışı ürün veren tür veya türlerin biyolojisi, ekolojisi gibi hususlar göz önünde bulundurulmak sureti ile saha bakım şartnamesi hazırlanir" (OGM, 2016) denmektedir. Ancak bu noktada türe ve ürüne özgü bir bakım şartnamesi hazırlaması istenen uygulayıcıya, idarenin yayınladığı tebliğle, bilim dünyasının gerçekleştirdiği araştırma ve yayınlarla nasıl bir bilgi sağlanabildiği sorgulanmalıdır.

\subsubsection{Tebliğin odun dışı ürünlere özel hükümleriyle ilgili bulgular}

302 sayılı tebliğ yukarıdaki bilgilere ek olarak, bazı odun dişı orman ürünlerine özel hükümler de içermiştir. Bu ürünler tebliğdeki sırasıyla incelenmiş ve aşağıdaki bulgular elde edilmiştir.

Tebliğde faydalanma anlayışı en net açıklanan ürün, reçinedir. Tebliğe göre reçine üretiminde asit pasta metodu kullanılacaktır. Bilindiği gibi reçine üretiminin Mazek yöntemi, kabuk yontma ve asit tatbiki metodu, kapalı yara yöntemi gibi başkaca metotları da vardır (Bozkurt ve Göker, 1981) ve tebliğ bu metotlardan asit pasta yöntemini tercih etmiştir. Asit pasta yönteminin doğruluğu veya yanlışlığ tartışılabilir fakat tebliğin olası yöntemler içerisinden hangisini tercih ettiğini açıç̧a ortaya koyması yerindedir.

Tebliğ reçine üretiminde "Kötü bonitetli sahalarda yapılmayacak" demekte fakat örneğin kızılçamda kötü boniteti tanımlamamaktadır. Tebliğe göre; "10 cm yara genişliği, ăgzı ayarlanmışs standart kızıllatma rendeleri, 12 $\mathrm{cm}$ eninde akıtma oluğu ve ă̆ız genişliği $13 \mathrm{~cm}$ toplama kaplarl kullanılacak, üretimde \%60'lık sülfürik asit (H2SO4), silika jel ve kaolinin çeşitli yüzdelerle karıştırılması sonucu hazırlanan asit-pasta ve pasta sürülmesinde 50 cc'lik plastik enjektörler kullanılacak, yaptırılan asit-pastanın Ormancılı Araştırma Enstitülerinde kontrolü sağlanacaktır" (OGM, 2016). Tebliğin nicel değişkenlerle ve ayrıntılı bir şekilde üretim sürecini tanımlaması, izleme konusunda bir birimi görevlendirmesi doğrudur fakat sürekliliği kontrol edecek bir veya birden fazla değişkeni (yıllık üretim miktarı, üretime alınabilecek orman alanı düzeyi vb.) tanımlamaması eksikliktir. İzleme ve değerlendirme değişkenleri tanımlamadan sürekliliği takip etme yaklaşımı ne yazık ki aşağıdaki tüm ürünlerde mevcuttur.

Sığla yağı: Reçine kadar net ifadeler taşımasa da, üretim tekniği uygulamaya yön verebilecek içerikte tanımlanmıştır. Yapılan açıklamaların $1 \mathrm{~d}(20 \mathrm{~cm}$ ve daha yukarı çaplardaki ăgaçlarda üretim yapılacağından) ve 3a (Üretim için seçilen sahada bizzat İsletme Şefi tarafindan sağlıklı, gövde çapı $15 \mathrm{~cm}$. den yukarl olan, yanma ve mantarlaşma görülmeyen ăgaçlar işaretlenecektir) maddelerinin çelişmesi gibi mantıksal sınamalara ihtiyaç duyulsa da, sığla yağı ürününün elde edilmesine yön gösterebilecek bir düzenleme yapılmıştır.

Çıralı çam kök odunu: Tebliğe göre üretim alant; "gençleştirme çalışması alanları ile erozyona maruz ve erozyon tehlikesi olan sahalar dışında" seçilecektir. Ayrıca üretime başlama ve bitirme tarihlerinin bölgenin mevsim şartları ve diğer ormancılık faaliyetleri ile yapılacak işin kapasite ve şartlarına göre idare tarafından belirlenmesi öngörülmüştür (OGM, 2016). Tebliğde, üretim yeri tanımlanmaya çalışılmışsa da, üretim zamanı belirsiz bırakılmış ve sorumluluk uygulayıcıya aktarılmıştır.

Defne yaprağı: Tebliğe göre "Defne yaprağ defne ăgacinin biyolojik yaplsi dikkate alınarak tek tek yaprak toplanmayacak, 2-3 yaşındaki yaprakl sürgünler kesilerek uygulama yaptlacaktır. Planlanan sahalar üç kesim parseline ayrlarak dönüşümlü üretime konu edilecektir" (OGM, 2016). Bu açıklamalar aslında, odun hammaddesi yönetimi veya mera amenajmanında da kullanılan; dönüş süresi üç yıl olan maktalı işletme yönteminin uygulanacağını ifade etmektedir. Ancak, 2 veya 3 yaşındaki sürgünlerin kesilebileceğini öngören tebliğin, neden 3 kesim parseli oluştururken, (dönüş süresi alırken), bazı yerlerde neden 2. yaşta kesime izin verdiği belirsizdir. Tebliğde defnenin vejetasyon dönemi tamamlandıktan sonra hasat edileceği belirtilmekte, elde edilecek uçucu yă̆ miktarı ile hasat zamanı ilişkisine (Erden vd., 2006; Güler ve Baş, 2006; Yazıcı, 2006) değinmeden faydalanma zamanı sadece vejetasyona bağlanmaktadır.

Çam fistığı: Fistık çamının asli ürününün fistık olduğunu belirten 302 sayılı tebliğ, bir orman ağacı olan bu türün, fistık verimi açısından aynı yaşlı, seçme orman tiplerinden hangisine göre yönetileceği, aynı yaşlı işletilecekse idare sürelerinin ne olacağı konularında bilgi vermemektedir. Meyve verimi açısından "etkili olması için fazla ısı ve ışı k alacak kapalılık sağlanacak" denmekte fakat kapalılık sınıfı 
veya düzeyi net bir şekilde belirtilmemektedir. Silvikültür mevzuatında belirtilen şekilde budamanın yapılacağ belirtilirken, "Genç meşcerelerde gençlik ve sıklık bakımı yapilacak" denilmekte fakat bunun nasıl yapılacağ açıklanmamaktadır. Yeni tesis edilecek fistık çamı meşcereleri için uygun dikim aralıkları önerilmediği gibi, bu türle birlikte gerçekleştirilme olasılığı yüksek karma ormancilık veya silva pastoral sistemler uygulanmak istendiğinde, izlenecek yaklaşıma da yer verilmemektedir.

Şimşir sürgünü: Bilindiği gibi şimşirin hem sürgününden hem odunundan yararlanılmaktadır. Yüksek odun kalitesiyle el sanatlarının aranan hammadde kaynağı olan şimşir, 302 sayılı tebliğde sadece sürgün kaynağı olarak görülmüştür. Oysa sürgün faydalanmasına konu olan bir ağacın asimilasyon yüzeyi azalır ve odun artımı, üretimi de etkilenir. $\mathrm{Bu}$ nedenle, sürgün yararlanması yapılan bir türün odun üretimini de etkilediği bilinmelidir. Tebliğde "Şimşir sürgün üretimi yapılması planlanan sahalar, beş ayrı kesim sahasina bölünür, beş yılda bir dönülmek kaydı ile her yll bir kesim sahasinda üretime müsaade edilir" (OGM, 2016) denilerek, esasen beş yıl dönüş süreli, maktalı bir işletme şekli benimsenmiştir. Tebliğe göre, "Sürgünler, kullanım amacına uygun olarak $15 \mathrm{~cm}$ boydan küçük olmayacaktır". Beş yıllık dönüş süresi ile $15 \mathrm{~cm}$ kısıtı birlikte değerlendirildiğinde, sürekli bir üretim için, bir sahanın hasat sonrasındaki beş yıl içerisinde yeniden $15 \mathrm{~cm}$ sürgün verebileceğinin varsayıldığı görülmektedir. Oysa $\mathrm{Ok}$ ve arkadaşlarının İstanbul piyasası ve Ağva ormanlarında yaptığı araştırma, çiçekçilerin $40-50 \mathrm{~cm}$ uzunluğunda sürgün talep ettiklerini, Ağva koşullarında bu sürgünün 7 yılda elde edilebildiğini göstermiştir (Ok vd., 2012). Tebliğde, şimşirlerin nasıl bir bitki örtüsü oluşturduğu, meşcere yapısı itibariyle nasıl bir tablo göstermesi gerektiğine dair açıklamalar yoktur. Çoklukla dere kenarlarında ve alt tabakada yer alan ve tahrip görmüş şimşir sahalarının, hangi tedbirlerle ideal sürgün ve odun üretim sahalarına dönüştürülebileceğine dair, uygulamaya yön gösterebilecek bilgiler yer almamaktadır.

Meşe mazısı: Tebliğe göre mazı üretim metodu "mazıların elle veya bir sırık yardımıyla düşürülerek toplanması" (OGM, 2016) şeklinde sade bir yöntemdir. Tebliğ açıklamalarında üretime mazıların olgunluğa eriştikleri 15 Ağustos'ta başlanacağı, üretim süresinin kısa tutulacağı ve Eylül ayının başında bitirileceği ifade edilmekte ve "Eylül ayı içerisinde kurt mazıyı delerek dışarı çıkmakta, yağan yăgmurlardan mazıda kalite kaybına sebebiyet vermektedir" (OGM, 2016) şeklinde bir uyarı yapılmaktadır. Ancak, söz edilen kurdun biyolojik devamlılığının bir sonucu olan mazı üretiminin, sürekli olarak, kurt yaşam evresini tamamlamadan yapıldığında bitebileceği unutulmuştur. $\mathrm{Bu}$ nedenle, tebliğin mazı sürekliliğini sağlayacak bir bakışla hazırlandığını söylemek, biyolojik açıdan olanaksızdır. Var olan mazıların bir kısmının hasat edilirken, bir kısmının bırakılarak, kelebek çıkmasına izin verilmesi ve ardından yumurtlayarak sonraki yılın mazılarını yaratacak böcek popülasyonu devamlılığının dikkate alınması gereklidir.

Meşe palamudu: 5-10 yaşındaki ağaçlarda palamut veriminin başladığı ve 2 yılda olgunlaşan meyvelerin, en bol olarak 25 yaşında meyve veriminin elde edildiği belirtilen 302 sayılı tebliğde, iyi bir palamut üretimi için nasıl bir meşe meşceresi kurmak gerektiği, aynı yaşlı veya seçme orman tiplerinden hangisinin uygun olduğu veya ideal bir idare süresinden söz edilip edilemeyeceği belirsiz bırakılmıştır. Budama ve bakım konularında da bir öneri yer almamaktadır. Sepi maddesi zenginliğinin en bol olduğu Ağustos ayında üretimin yapılması istenmekte fakat 2 yılda olgunlaşan meyvelerden hangilerinin iki yıla geldiğine nasıl dikkat edileceği veya yaban hayatı açısından ne kadarının toplanmadan bırakılmasının "sürdürülebilir ekosistemler" açısından gerekli olduğu bildirilmemektedir. Bunlara hiç değinilmeden "üretim metodu" olarak ucu kancalı sırık kullanılması önerilmekte, diri örtü temizliği yapılmasına yönelik ifadelerle yetinilmektedir.

Ardıç meyvesi: Meşe palamudunda yapılanın aksine, ardıç meyvesinde olgunlaşma süresinin dikkate alındığ görülmektedir. Tebliğde yer alan "Ardıç ăgacı üzerinde 1 ve 2 yıllık kozalaklar bulunduğundan, 1 yıllık kozalakların ve sonbaharda meydana gelen erkek çiçeklerin tahrip edilmemesine özen gösterilecektir" (OGM, 2016) ifadesinden biyolojik bir kısıdın dikkate alındığ anlaşılmaktadır. Ekim, Kasım aylarında olgunlaşma tamamlandıktan sonra toplamanın yapılması da ardıcın sürekliliği açısından doğrudur. Ancak ne kadar kozalağın yenilenme ve yaban hayatı açısından doğaya bırakılması gerektiği, tebliğde belirsizdir. Ardıç meşcerelerinin iyi bir kozalak verimi için nasıl bir yapıya eriştirilmesi gerektiği, ideal idare süreleri ve bakım çalışmalarına ise değinilmemiştir.

Ihlamur çiçeği ve yaprağı: Tebliğ, Ihlamur yaprak ve çiçeklerinin üretim metodunu açıklamak için "Ihlamur çiçek ve yapraklarının üretimleri ağaçlara çıkarak elle veya ăgaçlara zarar vermeden küçük dal makaslarıyla kesilerek yapılacaktır. Dal kesimine müsaade olunmayacaktır" (OGM, 2016) demeyi ve kurutma koşullarından söz etmeyi yeterli bulmuştur. Tebliğ, iyi bir çiçek verimi ile yaş, sıklık, kapalılık ilişkisinden veya tepe çatısının yapısı ile budama tekniklerinden söz etmediği gibi, ıhlamur ağaçlarının bakım koşullarından da söz etmemektedir. Ihlamur üretimiyle yaban hayatı ve bal üretimi ilişkisi dikkate alınmamış, çiçek hasatının bu alanlarda yapabileceği olumsuzluklar dışlanmıştır.

Huş üretimi: Yaprak kabuk ve ince dalları ilaç sanayiinde kullanılan Huş’un üretim tekniği 302 sayılı tebliğde üç madde halinde açıklanmıştır. Bu açıklamalarda, üretimin yaprakların çıkmaya başladığı yaz başında ve iki ay içerisinde, elle yapılacağı, dallar için uygun kesici aletlerin kullanılacağı belirtilmektedir. Kabuk üretiminin orta yaşlı ve yaşı ağaçlardan yapılacağı ifade edilmekte fakat hangi yaşların orta, hangilerinin yaşlı kabul edileceği belirsiz bırakılmaktadır. Benzer şekilde, daha yaz başında hasat edilen yaprakların ağacın hayatiyeti üzerindeki etkilerinin dikkate alınmadığı ve "hasat edilebilir yaprak, dal ve kabuk" düzeyleri konusunda hiçbir üst sınır çizilmediği görülmektedir.

Okaliptüs yaprağı üretimi: Tebliğde üretim metodu tanımlanırken, Haziran ayı sonu ile Ağustos sonu arasında yaşlı ağaçlardan toplanması önerilen okaliptüs yaprakları konusunda da "yaşlı" ağaç niteliğinin alt yaş sınırının ve tek bir ağaçtan alınabilecek yaprak düzeyinin toplam yaprağa oranının belirsiz olduğu görülmektedir.

Keçiboynuzu meyvesi üretimi: Tebliğe göre ağaçlar 5 yaşında meyve vermeye başlamakta, ideal meyve verimi 2025 yaş arasında elde edilmektedir. Meyvelerin sırıkla veya elle toplanılacağı belirtilmekte fakat keçiboynuzu içeren sahaların bakımı ve yönetimiyle ilgili bir öneri getirilmemektedir. Sürdürülebilir keçiboynuzu meyve üretim alanları oluşturmak üzere, mevcut sahaların yaş, çap 
veya başkaca bir yaklaşıma göre planlanması konusunda açıklamalar mevcut değildir. Keçiboynuzu meyvesinin yaban hayatı ile ilişkisine yönelik uyarılar da bulunmamakta, doğaya terk edilmesi gereken meyve miktarı belirtilmemektedir.

Kestane üretimi: 302 sayılı tebliğ tek bir açıklama ile kestanede hem meyve, hem yaprak, hem de kabuk üretimini açıklamıştır. Aynı ağaçtan yapılacak kabuk ve yaprak üretiminin meyve üretimine olası olumsuz etkileri yok sayılmıştır. Kestane dal kanserine önlem olarak, sırıkla vurarak düşürmek yasaklanmakta fakat kestane meşcerelerinde yapılacak bakım, budama gibi öneriler yapılmamaktadır. Kestane gibi sürekli ve oturmuş bir pazarı olan bir türle ilgili yapay meşcerelerin kurulmasına, var olanların desteklenmesine yönelik bir yaklaşım görülmemektedir.

Cehri üretimi: Tebliğde kurak ve taşlı yerlerde yetişen cehrilerin "meyvelerinin Temmuz ayından itibaren olgunlaşmaya başladığı, Eylül ayında siyah renge dönüştüğü ifade edilmekte ve meyvelerin henüz olgunlaşmadığ Haziran ayl sonu ve Temmuz ayl başlarinda sanayide kullanım yönünden en uygun olduğu ifade edilerek toplama zamanı vurgulanmaktadır. Belirtilen zamanın sanayi için uygun olduğu dikkate alınmakta fakat bitkinin sürekliliğ $i$ açısından uygunluğu göz ardı edilmektedir. Konu yaban hayatı açısından irdelenmediği gibi, kurak ve taşlı bir yetişme ortamında henüz olgunlaşmadan tüm meyveleri toplanmış bir türün devamlılığını nasıl sağlayacağı konusunda bir önlem önerilmemektedir.

Mahlep üretimi: Anadolu'nun özellikle kurak bölgelerinde yer alan ve meyvelerinden yararlanılan bir diğer türü olan mahlepte de sadece üretim zamanını dikkate alan bir düzenleme yapılmıştır. Tebliğe göre "Haziran ayı sonlarında meyvelerin olgunlaşıp kuruyarak, renklerinin siyahıms-kırmızıya döndükleri zaman üretimine başlanacaktır" (OGM, 2016). Bu dönemde toplanacak meyve miktarı ile türün devamlılığı için doğaya ve yaban hayatına bırakılacak miktar konularında bir kısıtlama bulunmamaktadır. Mahlep çalı veya ağaçlarından ideal meyve verimini alabilmek için yapılması gereken bakım ve gençleştirme çalışmaları ile yeni mahlep alanları oluşturulması hakkında da öneriler yoktur.

Menengiç üretimi: Esasen menengiç üretimi aynı bitkiden üç ayrı ürünün (meyve, balzamik yağ ve mazı) alınabileceği karmaşık ve etkileşimli bir üretim sistemidir. Ancak tebliğde bu ürünler bir bütün olarak ele alınmış, balzamik yağ üretiminin meyve üretimine bir etkisinin olup olmayacağı irdelenmemiştir. Benzer şekilde, mazıların "Pemphigus conniculatus Pass isimli böcek tarafindan" (OGM, 2016) oluşturulduğu belirtilmiş fakat bu böceğin biyolojisi ile yapılan üretim ilişkilendirilmemiştir. Nitekim mazı üretiminin de meyvelerin olgunlaştığı Ağustos-Eylül aylarında yapılması önerilmiştir.

Sumak üretimi: Tebliğde, piyasa isteklerinin dikkate alınıp, bitkinin sürekliliği için hasat zamanının uygunluğunun sorgulanmadığı bir başka ODOÜ, sumaktır. Yaprak ve meyvelerinden yararlanılan sumağın, tebliğe göre son iki yıl sürgünleri alınacak ve "üretime, bitkideki yaprak sayısının ve yapraktaki tanen oraninin azami seviyeye ulaştığı Haziran ayı sonu ve Temmuz ayı başı yapraklarda bulunan ana damar oluşumunun tamamlanmasiyla başlanacak, orta damarın kızarmast ile (Eylül ayl) son verilecektir" (OGM, 2016). Bu şekilde yararlanmanın tohumun olgunlaşma, dökülme ve yeni bitkileri oluşturma açısından bir sakınca taşıyıp taşımadığı belirtilmemektedir. Ayrıca, toplanan meyvelerin yaban hayatı açısından bir önemine de atıf yoktur. Sürekli son iki yıl sürgünü alınan bitki gövdelerinin nasıl bir hal alacağı dikkate alınmamıştır. Uzun dönem gençleştirme, tek bitki veya bitki örtüsü ölçeğinde bakım konularında öneriler bulunmamaktadır.

Erika üretimi: Köklerinden yararlanılan Erikaların tebliğe göre "ana kök yan köklerden ayrllacak, üretimde sahanın tamamı köklenmeyecek, aralıkl ocaklar halinde kökler çıkarılacaktır". Bununla birlikte, tebliğ "Ballı bitki niteliğinde olan Erika'nın gezginci arıcılar tarafindan tercih ediliyor olması nedeni ile yayılış alanlarında arıcılık faaliyetleri de göz önünde bulundurularak üretim planlanmalı" (OGM, 2016) hükmünü getirmektedir. Kestane ve Ihlamurda dikkate alınmayan ve süreklilik ve üretimin diğer sosyal kesimlerle ilişkisini dikkate almak bakımından olumlu olan bu ifadeler, ne yazık ki, belirsizdir. Bir alandaki Erikalardan ne kadarının kökletilebileceği, aynı alanda hangi aralıklarla yararlanmaya izin verilebileceği ve kaç kovanlık bir koloni için en az ne kadarlık Erika bırakmanın doğru olacağı belirsizdir.

Sakız üretimi: Tebliğin önerdiği sakız üretim tekniği ağaç gövde ve dallarında yapılacak çiziği ve bu çizikten elde edilecek balsamın toplanmasını açıklayan bir içeriktedir. Çiziğin derinliği ve şekli verilmiş fakat bir ağacın toplam yüzeyinin ne kadarının çizilebileceği verilmemiştir. Benzer şekilde, ağaç yaşı ile sakız verimi ilişkisini dikkate alan öneriler yoktur. İdeal bir sakız verimi için bölgedeki Sakız ağaçlarının eriştirilmesi gereken en doğru meşcere yapısı, bu yapıyı koruyacak bakım önerileri bulunmamaktadır.

Kitre zamkı üretimi: Tebliğin, kısıtlamalar yaptığ 1 üretim biçimlerinden biridir. Tebliğe göre "gevenin toprak erozyonunu önleyici fonksiyonu yanında arıcllkta tercih edilen ballı bitki oluşu da göz önünde bulundurulmalıdır. Meyil gurubunun çok düşük olduğu, su ve rüzgâr erozyonunun olmadiğı alanlardan faydalanma yoluna gidilmelidir" (OGM, 2016). Tebliğin önerileri haklı fakat uygulayıcıya yol gösterebilecek açıklıkta değildir. Toprak erozyonu artık niceliksel olarak sinıflandırılabilen bir sorundur. Meyil grubu çok düşük yerine $\% \mathrm{x}$ şeklinde net verilmeli, arıcılık için hektarın hangi oranında yararlanma yapılabilirken, kaç arılık bir üretim için ne kadar geven bırakılması gerektiği açıklanmalıdır. Tebliğ "Aynı köklerden 1 yıl ara vermek şartıyla tekrar üretim yapılabilir" demekte fakat sahadan mekâna dayalı bir faydalanma - rotasyon planı önermemektedir.

Meyan kökü üretimi: Tebliğ meyan kökü üretiminin Ekim ve Kasım aylarında yapılmasını istemektedir. Tebliğe göre "Üç yıllık bitkinin toprak üzeri kısımlarının kurumaya başlaması ile toprak altında bulunan kök ve rizomları, insan gücü veya riperli güçlü traktörlerden yararlanılarak topraktan çıkarılır. Toplama sırasında toprakta belli aralıklarla bitki kökleri ve rizomları toplanmadan bırakılarak, kalanlarla aynı sahada bitkinin yeniden üremesi sağlanacaktır". $\mathrm{Bu}$ ifadelerden bir süreklilik kaygısı izlenmekte fakat belli aralığın ne olduğu bilinmediği gibi, sahanın üç yıllık bir faydalanma planına göre maktalara ayrılıp, her yıl sadece bir bölümde yararlanmanın yapılmasına neden izin verilmediği anlaşılamamaktadır.

Fındık ve Ceviz Üretimi: Kültüre alınmış bu iki cins ile ilgili, özellikle meyve olgunlaşma zamanı ve toplama şekli hakkında ilgili Tebliğde açıklamalara yer verilmiştir. Tarımsal deneyimden yararlanarak bu bilgileri daha da geliştirmek mümkündür. Ancak, asıl yapılması gereken, 
doğada tek tek veya meşcere vaziyetindeki yabani cinslerin sürekliliği açısından yapılması gereken bakım çalışmaları, yararlanma ile yaban hayatının ilişkisinin nasıl daha iyi sağlanacağı konularında uygulayıcıya yön gösteren açıklamalardır. Gerçekten de ayı gibi memelilerden, sincaplar gibi kemirgenlere ve kuşlara kadar uzanan geniş bir etkileşim ceviz ve findıkta görülmektedir. Bu nedenle, bu ürün ve cinslerle ilgili yönetim planlarının yaban hayatına etkileri mutlaka dikkate alınmalıdır.

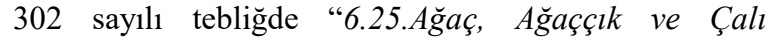
Formundaki Bazl Türlerin Toplama ve Üretiminde Uygulanacak Özet Bilgi Tablosu" (OGM, 2016) şeklinde bir değerlendirme de yer almaktadır. Bu tabloda yukarıdaki açıklamalarda yer almayan "andız kozalağı, frenk üzümü" gibi ürün ve türler ilk defa yer alırken, tebliğin önceki başlıklarında yer alan Cehri gibi ürünler bir defa daha yer bulmuştur. $\mathrm{Bu}$ nedenle, tebliğde önceki bilgilerin bir özetinin mi yapıldığ 1 veya ayrıntılı açıklanamayan ürün ve türler için, ek bilgi mi verilmek istendiği anlaşılamamıştır.

Tebliğde otsu bitkiler için de "üretime ait temel prensipler tablosu" yer almaktadır. Bu tabloda bitkinin kullanılan kısmı, toplanma zamanı, toplanma şekli, temizlenme ve kurutma biçimine yönelik öz bilgilere yer verilmiştir. Toplanma zamanının ürün için ideal zaman mı yoksa bitkinin devamlılığı için en uygun zamanı mı gösterdiği belirtilmemiştir. Önceki açıklamalara benzer şekilde, daha sürdürülebilir üretim için bitki yetiştirme, doğal yolla gelmiş bitkiye bakım yapma noktalarında türe özgü öneriler yer almamaktadır.

302 sayılı tebliğle açıklanan bir diğer önemli ODOÜ konusu, soğanlı bitkiler alanındadır. Tebliğ, bu konuda "Doğal Çiçek Soğanlarının Üretimi, Doğadan Toplanması ve İhracatına İlişkin Yönetmelik" hükümlerine de atıf yapmakta ve bu yönetmeliğe göre Bakanlık ve Üniversiteler ile Çevre kuruluşlarının iştirakinin sağlandığ Komitenin yararlanılacak türler listesini belirlediğini, kotalar koyduğunu, firmaları ve toplama yapacakları bölgeleri belirlediğini ifade etmekte ve "firmaların toplama planı” hazırladığını söylemektedir (OGM, 2016). Teknik komitenin kararları, hukuki olabilir fakat bilimsel dayanakları açıklanmadığı sürece, sürekliliği sağlayıp sağlayamadığı tartışmalı kararlar olarak kalmaya mahkûmdur. Bu türlerde toplama planını, toplama işinden kar bekleyen alıcı firmaların yapması ise belki de en çok tartışılması, sorgulanması gereken durumdur. Doğal kaynaklardan sorumlu idare, bu yetkisini terk etmiş, 302 sayılı Tebliğ de bu durumu hukukileştirmiştir. Soğanlı bitkilerin üretim tekniği diye tebliğde yer alan ifadeler çoklukla sökümü ve depolamayı açıklamakta, "2 yıl üst üste söküm yapılan saha üçüncü yılında dinlendirilecek ve söküm yaptırlmayacaktır", toplanma zamanı ve soğan çevresi gibi kısıtlamalar yapsa da, saha bütünlüğü içerisinde sürekliliği sağlayacak bir yönetim düzenini hedeflememektedir. Halbuki mera yönetiminde kullanılan münavebeli (dönüşümlü) otlatma mantığı içerisinde, soğanlı bitkilerde de bir ürün sürekliliği hedeflemek olanaklıdır.

302 sayılı Tebliğ mantarlara da yer vermiş̧tir. Buraya kadar irdelenen ODOÜ'lerden farklı olarak mantarlarda "doğaya bırakılması gereken" miktarlardan söz edildiği görülmektedir. Nitekim tebliğde "Mantarlar ocaklar halinde bulunduğundan toplama yapılan her ocakta 2- 3 adet mantar mutlaka toplanmadan bırakılmalıdır" şeklinde doğru bir ifade bulunmaktadır. Bütün dünyada mantarların ekolojik işlevleri, ne kadarının ürün, ne kadarının doğal sermeye olarak bırakılması gerektiği tartışma konusudur. Bu nedenle, 2-3 adet mantar ifadesi mantarlar için ve yaban hayatı için ayrı ayrı tartışma konusu yapılabilse de, bilimsel araştırmalarla ideal düzey belirlenebilecek durumdadır ve tebliğin buna yer vermesi, şimdilik yeterli görülmelidir. Bununla birlikte, diğer ODOÜ'lerinde olduğu gibi, "doğanın verdiğini en iyi şekilde almak" yaklaşımının mantarlara da yansitıldığı, daha üst mantar üretim düzeylerine erişebilmek için bir ormancı olarak yapılabilecekler konularında önerilerin geliştirilemediği görülmektedir. Hatta mantar hasadı konusunda sadece kesme sökme noktalarına odaklanıldığı, yağmur sonrası sahaya girmemek gibi iyi hasat yaklaşımlarına yer verilmediği anlaşılmaktadır.

\section{Tartışma ve sonuç}

Bilim dünyasının Türkiye'de gerçekleştirilen odun dışı orman ürünleri sempozyumlarında sunduğu bildirilerin anahtar kelimeleriyle, özetlerinde yönetim veya planlama kelimelerine yer veren bildirilerin oranı \% 6,7 ise de bu orandaki bildirinin ne kadar yönetim modeli önerebildiği tartışmaya açıktır. Sürdürülebilir bir yönetimin olmazsa olmazı olan izleme ve değerlendirme değişkeni önerebilme durumları ile bu oran karşılaştırıldığında, aslında izleme ve değerlendirme değişkeni içerebilenlerin daha fazla $(\% 26,2)$ olduğu görülmektedir. $\mathrm{Bu}$ durum, odun dişı ürünlerin yönetim veya planlamasını çalışanlar ile bu ürünlerin biyolojisi veya kimyasını çalışanların birbirinden bağımsız çalışmasının ve aslında yönetsel alana aktarılabilecek bilgilerin bağımsızca üretilmiş olmasının bir sonucudur. Gerçekten de, bir türün sürdürülebilir bir şekilde yönetilmesini sağlayacak planların, türün biyolojisine, üretim tekniğinin yapısına ve piyasanın isteklerine uygun izleme değerlendirme göstergelerine bağlanması gereklidir. Diğer yandan, elde edilen ürünlerden tatmin düzeyini veya başarı seviyesini belirlemek için, ürünlerin hasat zamanlarından içerdikleri aranan madde düzeylerine kadar farklı bilgileri, izleme-değerlendirme değişkenine dönüştürmek zorunludur.

Türkiye'de gözlenen tür ve ürün çeşitliliği, sürdürülebilir odun dışı orman ürünleri yönetiminin gerektirdiği farklı disiplinlerin bilgilerini tek bir ortak amaç doğrultusunda "bütünleştirme" ihtiyacını artırmaktadır.

302 sayılı tebliğin reçine gibi bilimsel bilgi üretimi yüksek alanlarda daha detaylı ve açıklayıcı ilkelere yer verebilirken, diğer önemli pek çok üründe, alternatif üretim tekniklerini nasıl dikkate aldığı bilinmeden, alışılmış üretim biçimini temel aldığı görülmektedir. Pek çok ürün için üretim tekniği diye tanımlanan bilginin, hasat etmekten ibaret bir içerikte olduğu açıktır. Ancak bu sonucu sadece tebliği hazırlayan birimlerin ilgi ve algısına bağlamak olanaksızdır. Reçinede alternatif üretim teknikleri geliştirilmişken, örneğin sığla yağında "geleneksel üretim biçimi" alternatifi olmayan bir şekilde uygulanmaya çalışılmaktadır. Odun dişı ürünlerin geleneksel üretim tekniklerine alternatif olabilecek teknikleri araştıran bilimsel çalışmalara ihtiyaç vardır.

Ormancilık mesleği, dünyada ve ülkemizde odun üretiminin planlanması ve sürdürülebilir yönetimi konusunda önemli bir birikime sahiptir. Odun üretiminin halen temel yöntemlerinden biri olan yaş sınıfları yaklaşımını odun dışı ürünlerin pek çoğunda uygulamak mümkündür. Odun üretiminde yıllarca başarıyla uygulanan 
kısa idare süreli baltalık işletme biçiminin, defne yapră̆ı, funda kökü, tavşan memesi gibi yaş ve alana bağlanabilecek türlerin yönetimine ilham kaynağı olmaması ilginçtir. Benzer durum mera amenajmanı yöntemleri için de geçerlidir. $\mathrm{Bu}$ alanlardaki yöntem birikimlerinin hangi türlerde nasıl bir uyarlama ile üretim tekniği haline getirilebileceği tartışılmalıdır.

302 sayılı tebliğde, odun dıșı ürün üretiminin hem ekolojik, hem ekonomik hem de teknik kısıtlarının bir bütün olarak tek bir üründe ele alınabildiği örneklerin azlığı dikkat çekmektedir. Hemen hemen tüm ürünlerde izleme ve değerlendirme ölçütü olabilecek değişkenlere tebliğde yer verilmemiştir. Tebliğde, öğüt vermek yaklaşımıyla bakıldığında doğru olan fakat uygulamaya yön gösteremeyen, k1lavuzluk yapamayan bilgilerle yetinildiği söylenebilir. Böylesi bir tebliği hazırlama deneyim ve birikimine sahip olanların, belirsiz bıraktığı bilgilerin hem deneyim, hem iş yükü açısından sıkıntılı durumdaki uygulayıcı birimlerce kapatılmasını beklemek olanaksızdır. Son yirmi yılda, defne yaprağı yönetimine katkı yapabilecek (Baş ve Güler, 2006; Erden vd., 2006; Güler ve Baş, 2006; Yazıc1, 2006; Parlak, 2011) çalışmalar olduğu gibi, fistıkçamı özelinde de çalışmalar (Kadıoğulları vd., 2006; Karademir vd., 2011) bulunmaktadır. Bu çalışma bulgularının 302 sayılı tebliğe neden yansitılamadığı, hem bilim hem uygulama dünyasınca tartışılmalıdır. Uygulayıcının ne kadar bilimsel çalışmaların farkında olması gerekiyorsa, bilim dünyasının da o kadar uygulayıcının yanıt aradığı sorularda ve netlikte bilgi üretmesi gereklidir. $\mathrm{Bu}$ nedenle, sadece yönetim ve planlama çalışanlar ile uygulayıcı birimler arasında bir eşgüdüm yeterli olmamakta, daha sürdürülebilir bir düzen kurmak için odun dışı ürün araştırması yapan tüm bilim insanları arasında bir uyumun sağlanması gerekmektedir.

OGM'nin geçmiş tebliğlerinde yaptığı gibi, odun dış1 orman ürünlerini hasat etmek isteyenlere verilecek izin ve satış işlemlerinden ibaret bir anlayışın 302 sayılı tebliğle, planlama ve yönetime doğru geliştirilmeye çalışılması olumlu bir değişimdir. Ancak, 302 sayılı tebliğde halen hasat odaklı bir bakışın egemen olduğu, hasat öncesi yönetim adına yapılması gerekenlerin neler olması gerektiğine yeterince önem verilemediği görülmektedir. Bu durumu anlamak için thlamur, keçiboynuzu veya kestane ile ilgili düzenlemeler yeniden incelenebilir. Tebliği hazırlayanlar, bu türleri yönetme sorumluluğunun sanki sadece ıhlamur çiçeği varsa ortaya çıktığını kabul ettikleri gibi bir yaklaşım sergilemiştir. $\mathrm{Bu}$ nedenle ülke odun dışı orman ürünü yönetimine "doğanın verdiğini hasat zamanında en iyi şekilde almak" yaklaşımının yön verdiği söylenebilir. Tebliğde, doğal veya yapay yolla daha iyi meyve verebilen, örneğin keçiboynuzu meşcerelerinin nasıl kurulacağı, bakımlarının nasıl yapılacağı konularına hiç değinmeden "yönetim" biçimi tanımlamak yeterli görülmüştür. Bu nedenle, tebliğin kapsadığı tüm türlerin, yeryüzüne gelişlerinden başlayan ve yaşam döngülerinin her evresinde yapılması gerekenleri içeren bir düzenlemeyi esas almak, süreklilik için şarttır. $\mathrm{Bu}$ nedenle, "doğanın verdiğini en iyi şekilde almak" yaklaşımının yerini, "daha sürdürülebilir bir odun dışı orman ürünü üretimi için doğayı desteklemek" anlayışı almalıdır. Bir başka değişle, nasıl alırımdan sürdürülebilirliği nasıl geliştiririm felsefesine geçilmelidir. Bu kapsamda bir tebliği hazırlamak için çok sayıda bilimsel çalışmaya ihtiyaç olduğu açıktır. Yararlanılması düşünülen odun dışı ürünle ilgili "hasat edilebilir düzeyi” belirlerken, yaban hayatı için bırakılması gereken ürün düzeyi ile türün kendi çoğalması için kalması gereken düzeyler hakkında bilimsel çalışmalar bir an önce tamamlanmalidir.

302 sayllı tebliği sistematik açıdan da yeniden yapılandırmak gereklidir. Genel bilgiler ile türe veya ürüne özel bilgiler karışmamalıdır. Geven üretimin planının arıcılığa etkisini dikkate almak gerekiyorsa, arıcılığa ve/veya bal üretimine etki eden tüm türlerin üretiminde bu etkiyi ele almak gereklidir. Odun dişı orman ürünleri yönetimi ne tek başına biyolojik ne de iktisadi bir olaydır. $\mathrm{Bu}$ nedenle, cehri, sumak veya mazıda olduğu gibi, pazarın isteklerini kısıt haline getirip biyolojik değişkenlerin dışlanması mümkün değildir. Bununla birlikte, üretim maliyetlerini karşılamayan, pazarda alıcısı olmayan bir üretimin de gerçekleştirilmesi olanaklı değildir. Bu nedenle, bu ürün ve türlerin planlanmasında hangi değişkenlerin nasıl dikkate alınacağı açıkça ortaya konmalıdır. Bu görevin başarılabilmesinin, farklı bilim dallarının, merak ettiklerini değil, planlama ve yönetim için gerekli bilgiyi üretmesiyle mümkün olacağı açıktır. Bu nedenle, OGM üst yönetiminin 302 sayılı tebliği, çok disiplinli bir bakış açısıyla yeniden gözden geçirmesi, belirsizlikleri tamamlama sorumluluğunu yerel uygulayıcı birimlere bırakmaması, eksiklik duyduğu bilginin üretimini ülkenin tüm araştırma kurumlarıyla birlikte, eksik bilgileri giderici politikalar ve uygulama planları geliştirmesi gereklidir.

\section{Açıklama}

Bu çalışma; 04-06 Ekim 2018'de Bursa'da düzenlenen 4. Uluslararası Odun Dışı Orman Ürünleri Sempozyumu'nda sözlü sunulmuş ve sadece özeti yayınlanmış bildirinin tam metnidir.

\section{Kaynaklar}

Açıkgöz, A.T., 2006. Odun dışı orman ürünleri ve sertifikasyon. I. Uluslararası Odun Dışı Orman Ürünleri Sempozyumu, 1-4 Kasım 2006,Trabzon, s. 167-173.

Alkan, H., Tolunay, A., Korkmaz, M., 2006. Isparta ilinde kekik yetiştiriciliğinin geliştirilmesine ilişkin yapılan çalışmaların değerlendirilmesi. 1. Uluslararası Odun Dışı Orman Ürünleri Sempozyumu, 1-4 Kasım 2006, Trabzon, s. 473- 487.

Altınçekiç, H., Çınar, A.S., Kırca, S., 2014. Orman içi rekreasyon alanı peyzaj projesi: Bandırma ili örneği, 3 . Uluslararası Odun Dışı Orman Ürünleri Sempozyumu, 8-10 Mayıs 2014, Kahramanmaraş, s. 831-841.

Aydın, Z.U., Bekiroğlu, S., 2014. Avcıların harcama eğilimleri (İstanbul ili örneği). 3. Uluslararası Odun D1şı Orman Ürünleri Sempozyumu, 8-10 Mayıs 2014, Kahramanmaraş, s. 17-25.

Baş, M.N., Güler, S., 2006. Defneliklerde alan ve servet envanter ile faydalanmanın düzenlenmesi. I. Uluslararası Odun Dışı Orman Ürünleri Sempozyumu, 1-4 Kasım 2006, Trabzon, s. 462-467.

Başkent, E.Z., Küçüker, D.M., 2011. Inventory of non wood forest products. H. Fakir, Ed., 2. Uluslararası Odun Dış1 Orman Ürünleri Sempozyumu, 8-10 Eylül 2011, Isparta, s. $229-237$. 
Bilgin, F., Şafak, İ., Kiracıoğlu, Ö., 2006. Ege bölgesinde defne üreticilerinin profili. 1. Uluslararası Odun D1ş1 Orman Ürünleri Sempozyumu, 1-4 Kasım 2006, Trabzon, s. 60- 65 .

Bozkurt, Y., Göker, Y., 1981. Orman Ürünlerinden Faydalanma. İÜOF Yayın no: 2840, 432 sayfa, İstanbul.

Carus, S., 2014. Biyometri ve odun dışı orman ürünleri envanteri. 3. Uluslararası Odun Dışı Orman Ürünleri Sempozyumu, 8-10 Mayıs 2014, Kahramanmaraş, s. 923-926.

Çiftçi, M., Fırat, Y., 2006. Türkiye'de ihlamur türleri ve faydalanma olanaklarının değerlendirilmesi. 1. Uluslararası Odun Dışı Orman Ürünleri Sempozyumu, 1-4 Kasim 2006, Trabzon, s. 124-131.

Çoban, S., Özalp, G., 2011. Silvicultural researches in boxwood areas used for ornamental shoots in Şile-A ̆gva Region. 2. Uluslararası Odun Dışı Orman Ürünleri Sempozyumu, 8-10 Eylül 2011, Isparta, s. 253-261.

Demirci, A., 2011. Türkiye'de odun dış1 orman ürünleri üretimi konusunda sorunlar ve çözüm önerileri. 2. Uluslararası Odun Dışı Orman Ürünleri Sempozyumu, 8-10 Eylül 2011, Isparta, s. 18-22.

Erden, Ü., Şekeroğlu, N., Özgüven, M., 2006. Defne (Laurus nobilis L.) yaprak uçucu yağ ve meyve sabit yağının mevsimsel değişimi. 1. Uluslararası Odun Dış1 Orman Ürünleri Sempozyumu, 1-4 Kasım 2006, Trabzon, s. 195- 201.

Ghanbari, S., Vaezin, S.M.H., Zobeiri, M., Shamekhi, T., Elahiyan, M.R., 2011. Financial evaluation of non-wood forest products in Arasbaran forests: A case study on cornelian cherry (Cornus mas) fruit in the forests of Kalaleh Village, Kalibar, Iran. 2. Uluslararası Odun Dışı Orman Ürünleri Sempozyumu, 8-10 Eylül 2011, Isparta, s. 1-6.

Güler, S., Baş, M.N., 2006. Defne (Laurus nobilis L.) yaprak verimi tahmininde yeni bir yaklaşım. 1 . Uluslararası Odun Dışı Orman Ürünleri Sempozyumu, 1-4 Kasim 2006, Trabzon, s.482- 487.

İlter, E., Ok, K., 2012. Ormancilık ve Orman Endüstrisinde Pazarlama İlkeleri ve Yönetimi. Genişletilmiş ve Geliştirilmiş 3. Baskı, ISBN: 978-975-96967-5-7, 423 sayfa, Ankara.

Kadıŏulları, A.İ., Mumcu, D., Demir, M., Günlü, A., 2006. Başlıca odun dışı orman ürünlerinin (kestane, fistıkçamı) miktar ve konumsal olarak dağılımının belirlenmesi. 1 . Uluslararası Odun Dışı Orman Ürünleri Sempozyumu, 1-4 Kasim 2006, Trabzon, s. 395-402.

Karademir, H., Kocabaş, H., Özen, İ., Kaleyıkan, F.K., Gediz, F., Yılmaz, F., 2011. Balıkesir ilindeki fıstıkçamı sahalarının durumu ve kırsal kalkınmadaki önemi. 2. Uluslararası Odun Dışı Orman Ürünleri Sempozyumu, 8-10 Eylül 2011, Isparta, s. 41-49.

Karahalil, U., Sivrikaya, F., Köse, S., Başkent, E.Z., 2014. Odun dışı bitkisel ürünlerden kekiğin orman amenajman planlarina entegre edilmesi: Köprülü Kanyon Milli Parki Örneği. 3. Uluslararası Odun Dışı Orman Ürünleri Sempozyumu, 8-10 Mayıs 2014, Kahramanmaraş, s. 275-285.

Karaköse, M., Terzioğlu, S., 2014. Finike (Antalya) merkez orman planlama biriminin odun dişı bitkisel ürünleri. 3 . Uluslararası Odun Dışı Orman Ürünleri Sempozyumu, 8-10 Mayıs 2014, Kahramanmaraş, s. 80-98.
Karaman, Ş., Diraz, E., Durdu, H., 2014. KahramanmaraşGöksun yöresinden toplanan Orthurus Heterocarpus (Boıss.) Juz. bitkisinin uçucu yağ bileşenlerinin tespiti. 3. Uluslararası Odun Dışı Orman Ürünleri Sempozyumu, 8-10 Mayıs 2014, Kahramanmaraş, s. 334-344.

Karı, Ü., Tutar, M., Çiçek, F., Sarı, A.O., 2014. Ege ve Batı Akdeniz florasında yayılış gösteren anadolu adaçayı (Salvia Fruticosa Mill). populasyonlarının bazı morfolojik, verim ve kalite özellikleri. 3. Uluslararası Odun Dışı Orman Ürünleri Sempozyumu, 8-10 Mayıs 2014, Kahramanmaraş, s. 717-726.

Keleş, S., Sivrikaya, F., Çakır, G., Başkent, E.Z., 2006. Orman ekosistemlerinin su üretim fonksiyonu ve orman amenajman planlarına yansitılmasi stratejileri. 1. Uluslararası Odun Dışı Orman Ürünleri Sempozyumu, 1-4 Kasim 2006, Trabzon, s. 488-497.

Kiriş, R., Çağatay, A., Demir, M., Mumcu, D., Kadıŏulları, A.İ., 2006. Odun dışı orman ürünlerinin planlanmasında karşılaşılan sorunlar ve çözüm önerileri. I. Uluslararası Odun Dışı Orman Ürünleri Sempozyumu, 1-4 Kasım 2006, Trabzon, s. 473-487.

Kitiş, Y.E., 2011. Bazı orman bitkilerinin biyopestisit olarak değerlendirilmesi. 2. Uluslararası Odun Dışı Orman Ürünleri Sempozyumu, 8-10 Eylül 2011, Isparta, s. 110117.

Korkusuz, E.E., Dirik, H., 2011. Gümüşi Ihlamur'un (Tilia tomentosa Moench) fenolojisi, çiçek özellikleri ve yararlanma esasları. 2. Uluslararası Odun Dışı Orman Ürünleri Sempozyumu, 8-10 Eylül 2011, Isparta, s. 201208.

Kulözü, N., Özer, S., Aklıbaşında, M., 2014. Kent ormanları konusunda kullanıcılarının farkındalık düzeylerinin saptanması: Erzurum kent ormanı örneği. 3. Uluslararası Odun Dışı Orman Ürünleri Sempozyumu, 8-10 Mayıs 2014, Kahramanmaraş, s. 746-755.

Kurt, R., Çabuk, Y., Karayılmazlar, S., 2011. türkiye odun dışı orman ürünleri (baharat ve baharat türevleri) diş ticaret analizi. 2. Uluslararası Odun Dışı Orman Ürünleri Sempozyumu, 8-10 Eylül 2011, Isparta, s.23-31.

Küçüker, D.M., Başkent, E.Z., 2014. The effects of stand, topographic and climatic characteristics on lactarius productivity in Kizılcasu planning unit. 3. Uluslararası Odun Dışı Orman Ürünleri Sempozyumu, 8-10 Mayıs 2014, Kahramanmaraş, s.107-115.

Lehtijärvi, A.T., 2006. Finlandiya'da yenen mantarlar ve kullanım alanları. 1. Uluslararası Odun Dışı Orman Ürünleri Sempozyumu, 1-4 Kasım 2006, Trabzon, s.352- 357.

Misır, N., Mısır, M., Yavuz, H., 2006. Çok Amaçlı Orman Envanterinde Odun Dışı Parametreler. I. Uluslararası Odun Dışı Orman Ürünleri Sempozyumu, 1-4 Kasım 2006, Trabzon, s.468-472.

Nakip, M., 2006. Pazarlama Araştırmaları Teknikleri ve (SPSS Destekli) Uygulamalar. Seçkin Yayıncılık, ISBN: 975-02-0310-0, Ankara.

NazariRad, M., Imangholiloo, M., Chehreghani, M., Abdia, S.H., Ghanbari, S., 2014. Forests of Iran and their nontimber forest products. 3. Uluslararası Odun Dışı Orman Ürünleri Sempozyumu, 8-10 Mayıs 2014, Kahramanmaraş, s. 178-182.

OGM, 2016. Odun Dışı Orman Ürünlerinin Envanter ve Planlaması İle Üretim ve Satış Esasları, Tebliğ No 302, Ankara. 
Ok, K., Tengiz, Y. Z., 2018. Türkiye'de odun dişı orman ürünlerinin yönetimi. Kahramanmaraş Sütçü İmam Üniversitesi Tarım ve Doğa Dergisi 21 : 457-471 http://dogadergi.ksu.edu.tr/issue/37038/428861.

Ok, K., Alagöz, G. Ö., Atıcı, E., Çoban, S., Şenyurt, M., 2012. Süsleme amaçlı kullanılan odun dişı orman ürünlerinin sürdürülebilir yönetimi. TÜBİTAK 109O264 Proje Sonuç Raporu, DOI: 10.13140/RG.2.1.1019.9764, https://www. researchgate.net/publication/282845134.

Özçelik, H., Koca, A., 2011. Türkiyede Kebere (Capparis L./ Capparaceae) cinsi ve ekonomik önemi. 2. Uluslararası Odun Dışı Orman Ürünleri Sempozyumu, 8-10 Eylül 2011, Isparta, s.32-40.

Özderin, S., Fakir, H., Erbaş, S., 2011. Muğla-Ula yöresinde doğal yayılış yapan bazı Hypericum sp. türlerinin uçucu yağ oranları ve bileşenlerinin belirlenmesi. 2. Uluslararası Odun Dışı Orman Ürünleri Sempozyumu, 8-10 Eylül 2011, Isparta, s.78-84.

Özer, S., Kulözü, N., Aklıbaşında, M., 2014. Kent ormanları kullanıcılarının memnuniyet düzeylerinin ve beklentilerinin saptanması: Erzurum kent ormanı örneği. 3. Uluslararası Odun Dışı Orman Ürünleri Sempozyumu, 8-10 Mayıs 2014, Kahramanmaraş, s.756-774.

Özkan, G., Fakir, H., Köylüoğlu, F., 2011. Seeds of Biebersteinia orphanidis Boiss. (Geraniaceae): Total phenolics and free radical scavenging activity of extract and oil composition. 2. Uluslararası Odun Dışı Orman Ürünleri Sempozyumu, 8-10 Eylül 2011, Isparta, s.96101.

Özmen, İ., Çelikoğlu, U., Yazıcı, S.Ö., Özçelik, H., Genç, H., 2011. Bazı Nepeta türlerlerinden elde edilen ekstraktların antioksidan aktiviteleri. 2. Uluslararas1 Odun Dışı Orman Ürünleri Sempozyumu, 8-10 Eylül 2011, Isparta, s.106-109.

Parlak, S., 2011. Defne (Laurus nobilis L.) yaprağı uçucu yağ oranlarının yörelere göre değişimi. 2. Uluslararası Odun Dışı Orman Ürünleri Sempozyumu, 8-10 Eylül 2011, Isparta, s.74-77.

Samba, L.E., Gertrude, A., 2011. Developing market place for non wood forest products in the North West Region of Cameroon. 2. Uluslararası Odun Dışı Orman Ürünleri Sempozyumu, 8-10 Eylül 2011, Isparta, s.10-12.

Sözbir, G.D., Beşikci, N., Alma, M.H., Bektaş, İ., Zülkadir, A., 2014. Kansere karş1 etkili Lentinus Edodes çürüklük mantarının kültürasyonu ve verim değerinin araştırılması. 3. Uluslararası Odun Dışı Orman Ürünleri Sempozyumu, 8-10 Mayıs 2014, Kahramanmaraş, s.383-390.
Şafak, İ., 2006. Ege Bölgesinde av ve yaban hayatı yönetimindeki sorunlar ve çözüm önerileri. I. Uluslararası Odun Dışı Orman Ürünleri Sempozyumu, 1-4 Kasım 2006, Trabzon, s.66-73.

Şafak, İ., Başar, H., 2014. Avcı derneklerinin amaçlarını etkileyen faktörlerin ekonometrik analizi. 3. Uluslararası Odun Dışı Orman Ürünleri Sempozyumu, 8-10 Mayıs 2014, Kahramanmaraş, s.7-16.

Şahin, Y., Üner, B., 2011. Sarıçam, Karaçam kozalaklarından elde edilen toplam fenolik, proanthocyanidins, flavonollerinin karşılaştırılması ve antioksidant özellikleri. 2. Uluslararası Odun Dişı Orman Ürünleri Sempozyumu, 8-10 Eylül 2011, Isparta, s.91-95.

Türker, M.F., Yeni, F. A., Genç, C., 2006a. Türkiye'de odun dışı orman ürünleri yönetimi ve işletmeciliğinin beş yıllık kalkınma planları ve ulusal ormancılık programı kapsamında değerlendirilmesi. 1. Uluslararası Odun Dışı Orman Ürünleri Sempozyumu, 1-4 Kasım 2006, Trabzon, s.74-82.

Türker, M.F., Pak, M., Öztürk, A., Durusoy, İ., 2006 b. Türkiye'de odun dışı orman ürünlerinin sürdürülebilir işletmeciliği: Mevcut durum, sorunlar ve çözüm önerileri. 1. Uluslararası Odun Dışı Orman Ürünleri Sempozyumu, 1-4 Kasım 2006, Trabzon, s.83- 92.

Türkoğlu, T., Büyüksakallı, H., Ulusoy, H., Yıldıztekin, M., 2014. Muğla Orman Bölge Müdürlüğü odun dişı orman ürünleri üretiminin zaman serileri analizi ile öngörüsü. 3. Uluslararası Odun Dışı Orman Ürünleri Sempozyumu, 8-10 Mayıs 2014, Kahramanmaraş, s.199-208.

Uzun, Y., 2006. Ardahan yöresinin konifer ormanlarında belirlenen bazı yenen ve zehirli makrofunguslar. 1 . Uluslararası Odun Dışı Orman Ürünleri Sempozyumu, 1-4 Kasim 2006, Trabzon, s.385- 392.

Var, A.A., 2006. Söke/Aydın civarının orman tali ürünleri, mahalli adları ve potansiyel kullanım maksatları. 1. Uluslararası Odun Dışı Orman Ürünleri Sempozyumu, 1-4 Kasim 2006, Trabzon, s.213- 220.

Yazıc1, H., 2006. Suni ve doğal yönetmelerle kurutulmuş defne yapraklarının sınıfsal özellikleri ve kayıp oranlarının tespiti. 1. Uluslararası Odun Dışı Orman Ürünleri Sempozyumu, 1-4 Kasım 2006, Trabzon, s.591- 597. 